\title{
Microstructure and Joining Properties of High Nb-containing TiAl Alloy Brazed Joints
}

\author{
Song Xiaoguo, Si Xiaoqing, Cao Jian, Wang Zhiquan, Zhao Hongyun, \\ Feng Jicai
}

State Key Laboratory of Advanced Welding and Joining, Harbin Institute of Technology, Harbin 150001, China

\begin{abstract}
High Nb-containing TiAl alloy (Ti-45Al-8.5Nb-(W, B, Y) (at\%), abbreviated as TAN alloy) was brazed at $1100{ }^{\circ} \mathrm{C}$ using $\mathrm{Ti}-28 \mathrm{Ni}(\mathrm{wt} \%)$ eutectic brazing alloy. The typical interfacial microstructure was $\mathrm{TAN} / \tau_{3}-\mathrm{Al}_{3} \mathrm{Ti}_{2} \mathrm{Ni}+\mathrm{B} 2 / \alpha_{2}-\mathrm{Ti}_{3} \mathrm{Al}$ layer $/ \alpha_{2}-\mathrm{Ti}_{3} \mathrm{Al}+$ $\delta-\mathrm{Ti}_{2} \mathrm{Ni} / \alpha_{2}-\mathrm{Ti}_{3} \mathrm{Al}$ layer $/ \tau_{3}-\mathrm{Al}_{3} \mathrm{Ti}_{2} \mathrm{Ni}+\mathrm{B} 2 / \mathrm{TAN}$. The effects of holding time on interfacial microstructure and joining properties of TAN brazed joints were investigated. The results demonstrate that the diffusion of $\mathrm{Ni}$ from molten brazing alloy to TAN substrate plays an important role in the interfacial microstructure evolution, which results in an increase of diffusion zone and a reduction of brazed seam with the prolongation of holding time. Shear test indicates that the maximum shear strength at room temperature and high temperature $\left(600^{\circ} \mathrm{C}\right)$ reaches $248.6 \mathrm{MPa}$ and $166.4 \mathrm{MPa}$, respectively when holding time is $15 \mathrm{~min}$. Fracture analyses reveal that brittle fracture prefers to initiate and propagate in the continuous intermetallic layers during shear test.
\end{abstract}

Key words: TiAl intermetallic; brazing; microstructure; mechanical properties; fracture

Intermetallic alloys demonstrate unique advantages in the aerospace and automotive fields, especially when weight saving of the components is a critical factor for structural applications ${ }^{[1,2]}$. TiAl based alloys are regarded as the most promising high-temperature structure materials due to their excellent properties, such as high specific strength, low density, good creep strength, as well as superior corrosion and oxidation resistance ${ }^{[3-5]}$. Within the family of TiAl based alloys, high $\mathrm{Nb}$-containing TiAl alloys (abbreviated as TAN alloys) are considered as a new generation TiAl based alloys. The increase of $\mathrm{Nb}$ content significantly improves high temperature strength, creep strength and high temperature oxidation resistance above $800{ }^{\circ} \mathrm{C}^{[6-9]}$.

Taking into account the practical applications of TiAl based alloys, the joining techniques of these alloys become especially important. Extensive investigations on joining TiAl based alloys have been carried out by fusion welding, friction welding, diffusion bonding and brazing ${ }^{[10-13]}$.
Among these techniques, brazing, as the most feasible and economical technique, has received considerable attentions in joining TiAl based alloys. In the case of brazing, the selection of appropriate brazing alloys is crucial in order to obtain satisfactory joints. It is reported that Ag based alloys have been successfully applied in brazing of TiAl based alloys $^{[14,15]}$. However, the TiAl joints brazed using Ag based alloys have low thermal resistance and the mechanical stability of the brazed joints badly degrades when service temperature is higher than $400{ }^{\circ} \mathrm{C}$. It means that the excellent high-temperature properties of TiAl based alloys cannot be used fully. Therefore, it is necessary to select brazing alloys with good high-temperature performance in order to meet the high-temperature serving conditions of TiAl brazed joints. Recent studies indicate that Ti based brazing alloys, including Ti-Zr-Cu-Ni-Co, Ti-Cu-Ni, Ti-Ni-V, Ti-Ni-Nb and Ti-Ni, demonstrate their advantages in brazing TiAl based alloys ${ }^{[16-21]}$. The joints brazed using Ti based brazing alloys possess high bonding strength and

$\overline{\text { Received date: January 21, }} 2017$

Foundation item: National Science and Technology Major Project (2014ZX04001131); National Natural Science Foundation of China (51405099, U1537206); Shanghai Aerospace Science and Technology Innovation Fund (SAST2015045)

Corresponding author: Song Xiaoguo, Ph. D., Associate Professor, Key Laboratory of Advanced Welding and Joining, Harbin Institute of Technology, Harbin 150001, P. R. China, E-mail: songxg@hitwh.edu.cn 
good corrosion resistance at ambient and elevated temperature due to the good compatibility between Ti based brazing alloy and TiAl substrate.

In this study, Ti-28Ni (wt\%) eutectic brazing alloy was fabricated to braze TAN alloy. The research focused on the effects of holding time on interfacial microstructure evolution and mechanical properties of TAN brazed joints. In addition, the fracture morphology of the brazed joints was also investigated.

\section{Experiment}

TAN alloy (Ti-45Al-8.5Nb-(W, B, Y) (at\%)) used in this study was provided by State Key Laboratory for Advanced Metals and Materials, Beijing, China. Fig.1a illustrates the micrograph of TAN alloy. The microstructure displayed a lamellar characteristic and a small amount of Nb-rich phases were randomly distributed in it. The brazing alloy with an eutectic composition of $72 \mathrm{Ti}-28 \mathrm{Ni}$ (wt\%) was prepared by vacuum arc remelting technique using high purity $(99.9 \mathrm{wt} \%) \mathrm{Ti}$ and $\mathrm{Ni}$ foils. All the raw materials were cleaned by $1.5 \mathrm{HF}-2.5 \mathrm{HNO}_{3}-5 \mathrm{HCl}-91 \mathrm{H}_{2} \mathrm{O} \quad(\mathrm{mL})$ and saturated in $\mathrm{NaOH}$ solution $(c=2 \mathrm{~mol} / \mathrm{L})$ before vacuum arc remelting. The alloy ingots were turned and remelted at least ten times until the final mass loss of master alloy was less than $0.1 \mathrm{wt} \%$. A diffusion-annealing treatment was conducted at $850{ }^{\circ} \mathrm{C}$ for $10 \mathrm{~h}$ for homogenization. The $\mathrm{X}$-ray diffraction (XRD) analysis indicated that the obtained Ti-28Ni brazing alloy mainly consisted of $\operatorname{Ti}(\mathrm{s}, \mathrm{s})$ and $\delta-\mathrm{Ti}_{2} \mathrm{Ni}$, which were formed by the binary eutectic reaction of $\mathrm{L} \rightarrow \mathrm{Ti}(\mathrm{s}, \mathrm{s})+\delta-\mathrm{Ti}_{2} \mathrm{Ni}$. The differential scanning calorimetry (DSC) analysis of $\mathrm{Ti}-28 \mathrm{Ni}$ brazing alloy showed that the temperature of solidus and liquidus was 940 and $980^{\circ} \mathrm{C}$, respectively that had been obtained in our previous research ${ }^{[22]}$. In order to ensure the sufficient dissolution and reaction of brazing alloy, the brazing temperature was fixed at $1100{ }^{\circ} \mathrm{C}$ in this study.

The Ti-28Ni brazing alloy was processed into foils with a thickness of $0.5 \mathrm{~mm}$ by spark cutting. Both surfaces of foils were ground on $\mathrm{SiC}$ grit papers until its thickness was about $50 \mu \mathrm{m}$. The TAN alloy was cut into blocks with two kinds of dimensions $(12 \mathrm{~mm} \times 4 \mathrm{~mm} \times 3 \mathrm{~mm}$ and $4 \mathrm{~mm} \times 4 \mathrm{~mm} \times 3$ $\mathrm{mm})$. Prior to brazing, all of the faying surfaces were polished by $\mathrm{SiC}$ papers up to grit 1000 , and then ultrasonically cleaned in acetone for $10 \mathrm{~min}$. Subsequently, the Ti-28Ni foil was sandwiched between two TAN alloy blocks. A small pressure of $1 \mathrm{kPa}$ was applied to keep the assembly proper contact. Brazing was performed in a vacuum furnace with the vacuum atmosphere of (1.3 2.0) $\times$ $10^{-3} \mathrm{~Pa}$. The time-temperature brazing cycle is shown in Fig. $1 \mathrm{~b}$. The brazing temperature was maintained at $1100{ }^{\circ} \mathrm{C}$ and the holding time varied from $0 \mathrm{~min}$ to $180 \mathrm{~min}$.
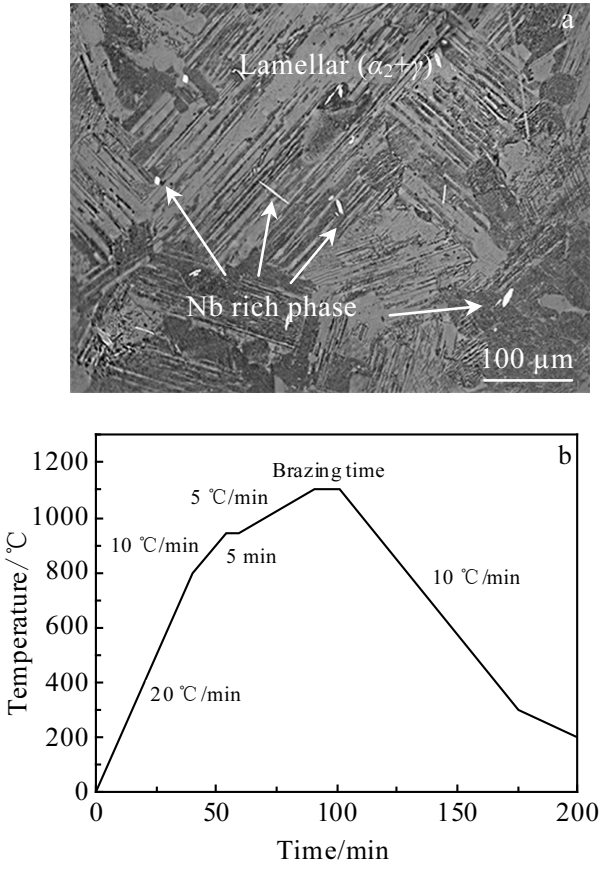

Fig.1 Microstructure of the TAN alloy (a) and time-temperature profile of the brazing cycle (b)

After brazing, the interfacial microstructure was characterized by scanning electron microscopy (SEM, Quanta 200FEG). The elemental distributions as well as componential analyses of various phases in the joints were carried out by an energy dispersive spectrometer (EDS, Hitachi TN-4700) with the operation voltage of $15 \mathrm{kV}$ and minimum spot size of $1 \mu \mathrm{m}$. The shear test was performed both at room temperature (RT) and at high temperature (HT) of $600{ }^{\circ} \mathrm{C}$ using a universal testing machine (Instron 1186) with a constant loading rate of $0.5 \mathrm{~mm} / \mathrm{min}$. At least five samples were used to average each set of experimental date in order for the accuracy of shear strength. Moreover, fracture analyses were conducted by SEM and XRD to determine the fracture locations and crack paths.

\section{Results and Discussion}

\subsection{Interfacial microstructure characterization of TAN brazed joints}

Reliable brazing of TAN alloy was achieved using Ti-28Ni brazing alloy at $1100{ }^{\circ} \mathrm{C}$ for $0 \sim 180 \mathrm{~min}$. Fig. $2 \mathrm{a}$ displays the representative interfacial microstructure of TAN joint brazed at $1100{ }^{\circ} \mathrm{C}$ for $15 \mathrm{~min}$ in backscattered electron (BSE) mode. The interfacial microstructure presents a symmetrical characteristic, which could be divided into two diffusion zones (I) and a brazed seam (II). The distributions of main elements in joint are illustrated in Fig. $2 \mathrm{~b} \sim 2 \mathrm{e}$. 


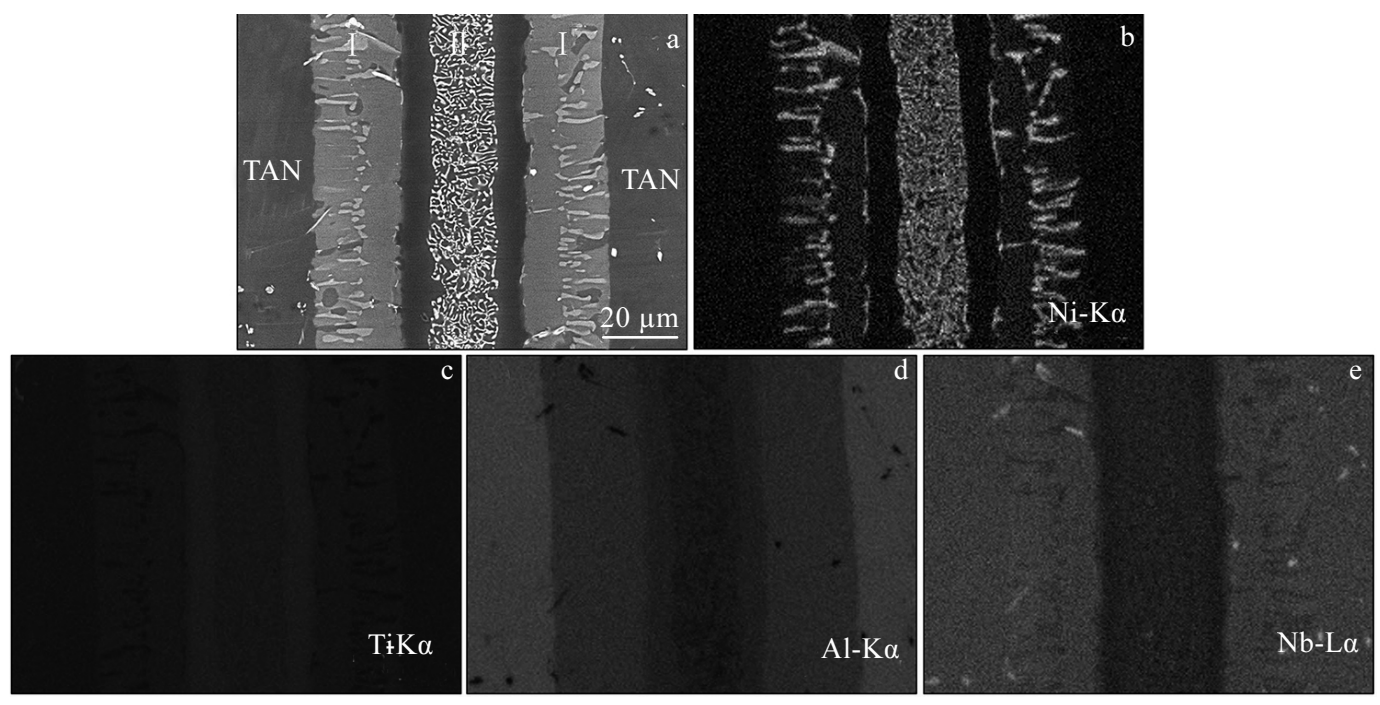

Fig.2 Interfacial microstructure and elemental distribution of TAN joint brazed at $1100{ }^{\circ} \mathrm{C}$ for 15 min: (a) BSE image of the joint and EDS maps of (b) Ni, (c) Ti, (d) Al, and (e) Nb

As shown in Fig.2b, the network Ni-rich phases are formed in the central region of brazed seam. Moreover, long-strip Ni-rich phase are formed in the diffusion zones with the diffusion of element $\mathrm{Ni}$ from molten Ti-28Ni brazing alloy into TAN substrate during brazing. According to the distribution map of element Ti shown in Fig.2c, it could be deduced that element Ti gathers at the solid/liquid interface, which causes the formation of continuous Ti-rich layers in brazed seam adjacent to diffusion zones. Fig.2d shows the distribution map of element $\mathrm{Al}$, which reveals a gradient-decreasing characteristic of element Al from TAN substrate to brazed seam. The distribution map of element $\mathrm{Nb}$ shown in Fig.2e indicates that element $\mathrm{Nb}$ as well as $\mathrm{Nb}$-rich phases are mainly distributed in TAN substrate and diffusion zone. Almost no element $\mathrm{Nb}$ could be found in brazed seam that might be due to its low content and slow diffusion rate.

In order to further investigate the interfacial microstructure, more details are presented in a larger visual field in BSE mode, as shown in Fig.3. The EDS results taken from the selected locations in Fig.3 are listed in Table 1. The highly magnified microstructure of diffusion zone shown in Fig.3a displays that the diffusion zone is mainly composed of two phases. The gray matrix phase (marked by A) has the average composition of $50.17 \mathrm{Ti}, 39.32 \mathrm{Al}, 2.46 \mathrm{Ni}$ and $8.05 \mathrm{Nb}$, which could be identified as B2 phase because elements $\mathrm{Nb}$ and $\mathrm{Ni}$ could stabilize the disordered HT $\beta$-phase and the ordered B2-phase ${ }^{[6-9]}$. The chemical composition of long-strip phases marked by $\mathrm{B}$ is $34.12 \mathrm{Ti}$, 43.39Al, $16.37 \mathrm{Ni}, 6.12 \mathrm{Nb}$. A relatively high content of $\mathrm{Ni}$ is in accord with the distribution map of Ni shown in Fig. $2 \mathrm{~b}$. The Al-Ni-Ti ternary alloy diagram and published literature

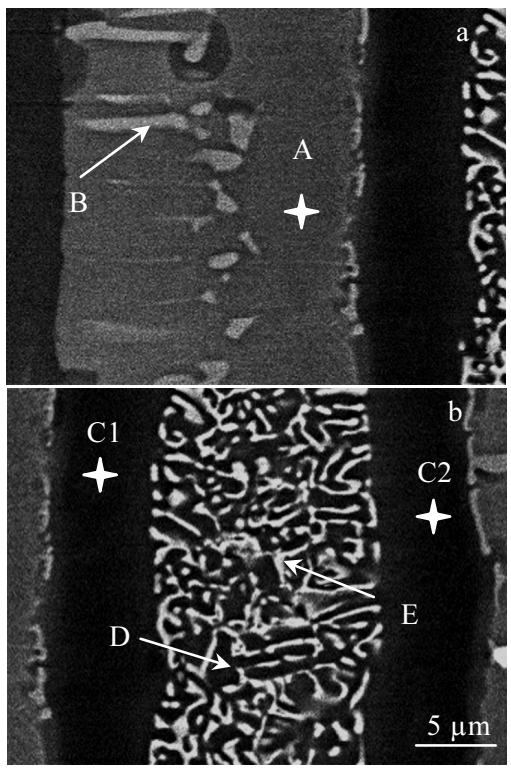

Fig.3 Highly magnified BSE images of TAN joint brazed at $1100^{\circ} \mathrm{C}$ for $15 \mathrm{~min}$ : (a) diffusion zone and (b) brazed seam

Table 1 EDS results of the selected locations in Fig.3 (at\%)

\begin{tabular}{cccccc}
\hline Spots & $\mathrm{Ti}$ & $\mathrm{Al}$ & $\mathrm{Ni}$ & $\mathrm{Nb}$ & Possible phase \\
\hline $\mathrm{A}$ & 50.17 & 39.32 & 2.46 & 8.05 & $\mathrm{~B} 2$ \\
$\mathrm{~B}$ & 34.12 & 43.39 & 16.37 & 6.12 & $\tau_{3}-\mathrm{Al}_{3} \mathrm{Ti}_{2} \mathrm{Ni}$ \\
$\mathrm{C} 1$ & 66.14 & 30.16 & 0.83 & 2.87 & $\alpha_{2}-\mathrm{Ti}_{3} \mathrm{Al}$ \\
$\mathrm{C} 2$ & 66.03 & 30.27 & 0.81 & 2.89 & $\alpha_{2}-\mathrm{Ti}_{3} \mathrm{Al}$ \\
$\mathrm{D}$ & 65.97 & 29.89 & 1.04 & 3.10 & $\alpha_{2}-\mathrm{Ti}_{3} \mathrm{Al}$ \\
$\mathrm{E}$ & 60.23 & 4.64 & 32.16 & 2.97 & $\delta-\mathrm{Ti}_{2} \mathrm{Ni}$ \\
\hline
\end{tabular}


show that $\tau_{3}$ phase with $\mathrm{MgZn}_{2}$-type structure has a large composition range from Al30Ni28Ti42 (at\%) to Al50Ni16Ti34 (at $\%)^{[23]}$. Therefore, the long-strip Ni-rich phases could be determined as $\tau_{3}-\mathrm{Al}_{3} \mathrm{Ti}_{2} \mathrm{Ni}$, which are consistent with the findings reported by Schuster ${ }^{[24]}$ and our previous studies $^{[18,19]}$.

Fig. $3 \mathrm{~b}$ shows the highly magnified microstructure of brazed seam. It is obviously seen that the brazed seam contains two continuous reaction layers and a two-phase mixed region. The EDS results of continuous reaction layers (marked by $\mathrm{C} 1$ and $\mathrm{C} 2$ ) suggest the presence of $\mathrm{Ti}$ and $\mathrm{Al}$ with the molar ratio of $3: 1$, which could be regarded as $\alpha_{2}-\mathrm{Ti}_{3} \mathrm{Al}$ phase. Moreover, the dark phase in two-phase mixed region marked by $\mathrm{D}$ has a similar chemical composition to the continuous reaction layers, and thus the phase could also be identified as $\alpha_{2}-\mathrm{Ti}_{3} \mathrm{Al}$. T he EDS analysis indicates that the network white phase marked by $\mathrm{E}$ has an average composition of $60.23 \mathrm{Ti}$, $4.64 \mathrm{Al}, 32.16 \mathrm{Ni}$ and $2.97 \mathrm{Nb}$, which corresponds to $\delta-\mathrm{Ti}_{2} \mathrm{Ni}$ phase. Therefore, the typical interfacial microstructure of
TAN joint is $\mathrm{TAN} / \tau_{3}-\mathrm{Al}_{3} \mathrm{Ti}_{2} \mathrm{Ni}+\mathrm{B} 2 / \alpha_{2}-\mathrm{Ti}_{3} \mathrm{Al}$ layer $/ \alpha_{2}-\mathrm{Ti}_{3} \mathrm{Al}+\delta$ - $\mathrm{Ti}_{2} \mathrm{Ni} / \alpha_{2}-\mathrm{Ti}_{3} \mathrm{Al}$ layer $/ \tau_{3}-\mathrm{Al}_{3} \mathrm{Ti}_{2} \mathrm{Ni}+$ B2/TAN.

\subsection{Effect of holding time on the interfacial microstructure of TAN brazed joints}

Fig. 4 shows the interfacial microstructure of TAN joints brazed at $1100{ }^{\circ} \mathrm{C}$ for different holding time. It could be clearly seen that all of the TAN brazed joints consist of a brazed seam and two diffusion zones. However, the interfacial morphology changes significantly with the prolongation of holding time, which indicates that the holding time has a great influence on the interfacial microstructure. The width of diffusion zone gradually increases with prolonging the brazing time. On the contrary, the width of brazed seam first decreases gradually and then remains constant when the holding time is over 60 min, which is caused by the phenomenon that the two-phase mixed region $\left(\alpha_{2}+\delta\right)$ reduces significantly and the continuous $\alpha_{2}-\mathrm{Ti}_{3} \mathrm{Al}$ layer presents a slight increase with the prolongation of brazing time. When TAN alloy is brazed
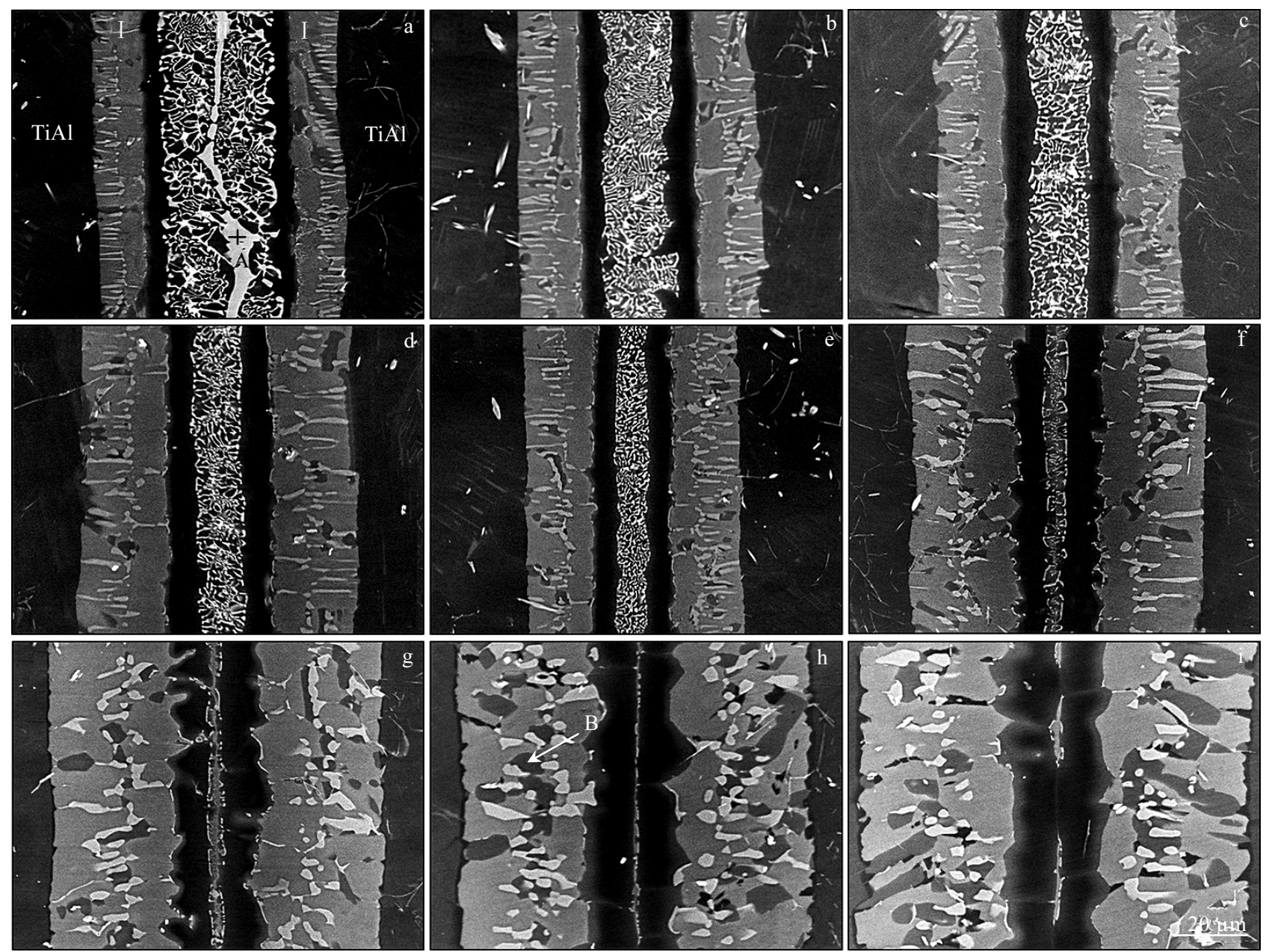

Fig.4 Interfacial microstructures of TAN joints brazed at $1100{ }^{\circ} \mathrm{C}$ for different time: (a) $0 \mathrm{~min}$, (b) $5 \mathrm{~min}$, (c) $10 \mathrm{~min}$, (d) $20 \mathrm{~min}$, (e) 25 min, (f) $60 \mathrm{~min}$, (g) $90 \mathrm{~min}$, (h) $120 \mathrm{~min}$ and (i) $180 \mathrm{~min}$ 

for 0 min, a continuous $\delta$ - $\mathrm{Ti}_{2} \mathrm{Ni}$ layer (marked as A in Fig.4a) is formed in the central region of brazed seam due to an insufficient diffusion of element Ni. Moreover, both of B2 phases and $\tau_{3}-\mathrm{Al}_{3} \mathrm{Ti}_{2} \mathrm{Ni}$ phases in diffusion zones grow up significantly when holding time is over $90 \mathrm{~min}$, as shown in Fig.4g 4i. Besides, some dark-gray massive $\gamma$-TiAl phases are formed in diffusion zones, as marked by B in Fig.4h.

Based on above analyses of interfacial microstructure, the formation process and microstructure evolution of TAN joint brazed using Ti-28Ni alloy could be elaborated as follows: Ti-28Ni foil begun to melt when the brazing temperature exceeded its melting point $\left(940{ }^{\circ} \mathrm{C}\right)$ and subsequently wetted the faying surfaces of TAN alloy, which produced a solid/liquid interface in the joint. The diffusion of $\mathrm{Ni}$ from molten brazing alloy into TAN substrate resulted in the formation of diffusion zones that mainly consisted of $\mathrm{B} 2$ phases and $\tau_{3}-\mathrm{Al}_{3} \mathrm{Ti}_{2} \mathrm{Ni}$ phases. Meanwhile, the Ti atoms in molten brazing alloy reacted with TAN substrates by the reaction of $\mathrm{Ti}_{(\mathrm{L})}+\mathrm{TiAl}_{(\mathrm{S})} \rightarrow$ $\mathrm{Ti}_{3} \mathrm{Al}_{(\mathrm{S})}$ to form continuous $\alpha_{2}-\mathrm{Ti}_{3} \mathrm{Al}$ layers at the solid/liquid interfaces. It could be deduced that the solid-liquid reaction was completed in a short time because the continuous $\alpha_{2}-\mathrm{Ti}_{3} \mathrm{Al}$ layer was insensitive to the holding time. The continuous $\alpha_{2}-\mathrm{Ti}_{3} \mathrm{Al}$ layer acted as a barrier layer to hinder the interactions between molten brazing alloy and TAN substrate, which was also reported by Lin et al ${ }^{[20]}$. Thus, once the $\alpha_{2}-\mathrm{Ti}_{3} \mathrm{Al}$ layer was formed, the diffusion rates of $\mathrm{Ni}$ and $\mathrm{Ti}$ atoms into TAN substrate as well as the dissolution rate of TAN substrate into molten brazing alloy were lowered. During the subsequent cooling process, the remnant liquid phase transformed to $\alpha_{2}-\mathrm{Ti}_{3} \mathrm{Al}$ phases and $\delta-\mathrm{Ti}_{2} \mathrm{Ni}$ phases, which caused the formation of a two-phase mixed region in brazed seam.

It is not difficult to find in Fig.4 that the changes of interfacial microstructure with prolonging holding time are mainly attributed to the diffusion of element $\mathrm{Ni}$ from molten brazing alloy into TAN substrate. The study of Y. Mishin and Chr. Herzig demonstrated that the Ni was a fast diffuser, with the diffusion coefficient being more than even three orders of magnitude higher than the coefficients of Ti and $\mathrm{Al}$ in $\gamma$-TiAl and $\alpha_{2}-\mathrm{Ti}_{3} \mathrm{Al}$ phases ${ }^{[25]}$. Therefore, the diffusion of $\mathrm{Ni}$ from residual liquid phase to TAN substrate could continue to rapidly carry out through the continuous $\alpha_{2}-\mathrm{Ti}_{3} \mathrm{Al}$ layer, which results in the increase of diffusion zones as well as the reduction of two-phase mixed region with the prolongation of holding time. When prolonging the holding time to $180 \mathrm{~min}$, almost all the element $\mathrm{Ni}$ has diffused into the TAN substrate and the brazed seam mainly consists of single $\alpha_{2}-\mathrm{Ti}_{3} \mathrm{Al}$ phase, as shown in Fig.4i.

\subsection{Effect of holding time on the joining properties of TAN brazed joints}

The joining properties of the TAN joints brazed at 1100
${ }^{\circ} \mathrm{C}$ for different holding time were evaluated at RT and HT $\left(600{ }^{\circ} \mathrm{C}\right)$ by shear test. The results shown in Fig. 5 reveal that the shear strength of TAN joints increases firstly and then decreases with the prolongation of holding time. When holding time is $15 \mathrm{~min}$, the highest average RT shear strength and HT shear strength reach 248.6 MPa and 166.4 $\mathrm{MPa}$, respectively. In addition, XRD analysis was carried out on the fracture surfaces after RT shear test for TAN joint brazed at $1100{ }^{\circ} \mathrm{C}$ for $90 \mathrm{~min}$ and the result is shown in Fig.6. Phases involving $\gamma-\mathrm{TiAl}, \alpha_{2}-\mathrm{Ti}_{3} \mathrm{Al}, \delta-\mathrm{Ti}_{2} \mathrm{Ni}$, $\tau_{3}-\mathrm{Al}_{3} \mathrm{Ti}_{2} \mathrm{Ni}$ and $\mathrm{B} 2$ are detected, which confirm the above analyses about the interfacial microstructure and phases.

In order to investigate the relationships between jointing properties and interfacial microstructure, fracture analyses were performed by SEM and EDS. Fig.7a, 7c and 7e show the cross-section BSE images of TAN joints after RT shear test, which were brazed at $1100{ }^{\circ} \mathrm{C}$ for $0 \mathrm{~min}, 15$ min and $90 \mathrm{~min}$, respectively. The secondary electron (SE) images of corresponding fracture surfaces are illustrated in Fig. 7b, 7d and 7f. It is clearly seen that the failure of TAN joints always occurs at the brazed seam showing brittle fracture characteristic while the fracture locations vary with the holding time. When holding time is $0 \mathrm{~min}$, the cracks mainly initiate and propagate in the continuous $\delta$ - $\mathrm{Ti}_{2} \mathrm{Ni}$ layer, as shown in Fig.7a. Fig.7c and 7e show that the TAN joints fracture along the continuous $\alpha_{2}-\mathrm{Ti}_{3} \mathrm{Al}$ layer when holding time is $15 \mathrm{~min}$ and $90 \mathrm{~min}$. So, it is concluded that the TAN joints prefer to fracture in the continuous intermetallic layers. It is well known that the continuous intermetallic layers are harmful to the joints properties. Therefore, the TAN joints obtained under short holding time (eg. $0 \mathrm{~min}$ ) or long time (over $90 \mathrm{~min}$ ) have relatively low shear strength both at RT and HT due to the presence of continuous intermetallic layers such as $\delta$ - $\mathrm{Ti}_{2} \mathrm{Ni}$ layer or continuous $\alpha_{2}-\mathrm{Ti}_{3} \mathrm{Al}$ layer. Fig. 5 shows that the TAN joints brazed for 5 20 min have relatively high shear strength. Combined with the interfacial microstructure shown in Fig.4b 4d, it could be deduced that the two-phase mixed region could improve the joints

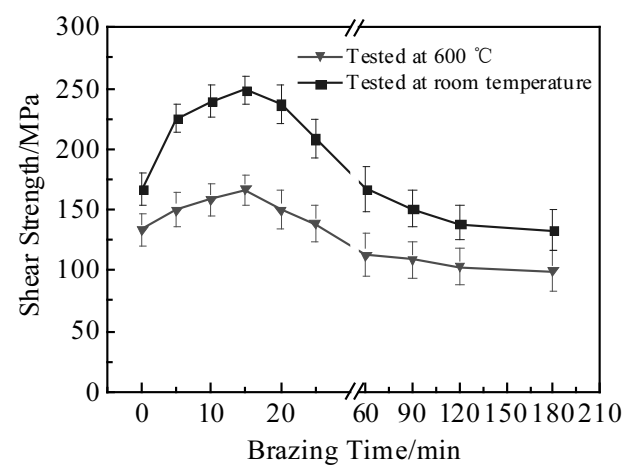

Fig.5 Effect of brazing time on shear strength of TAN joints brazed at $1100{ }^{\circ} \mathrm{C}$ 


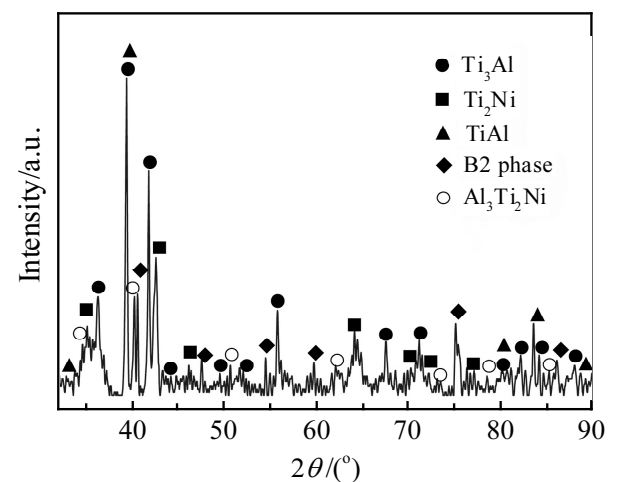

Fig.6 XRD pattern of the fracture surfaces after RT shear test for TAN joint brazed at $1100{ }^{\circ} \mathrm{C}$ for $90 \mathrm{~min}$

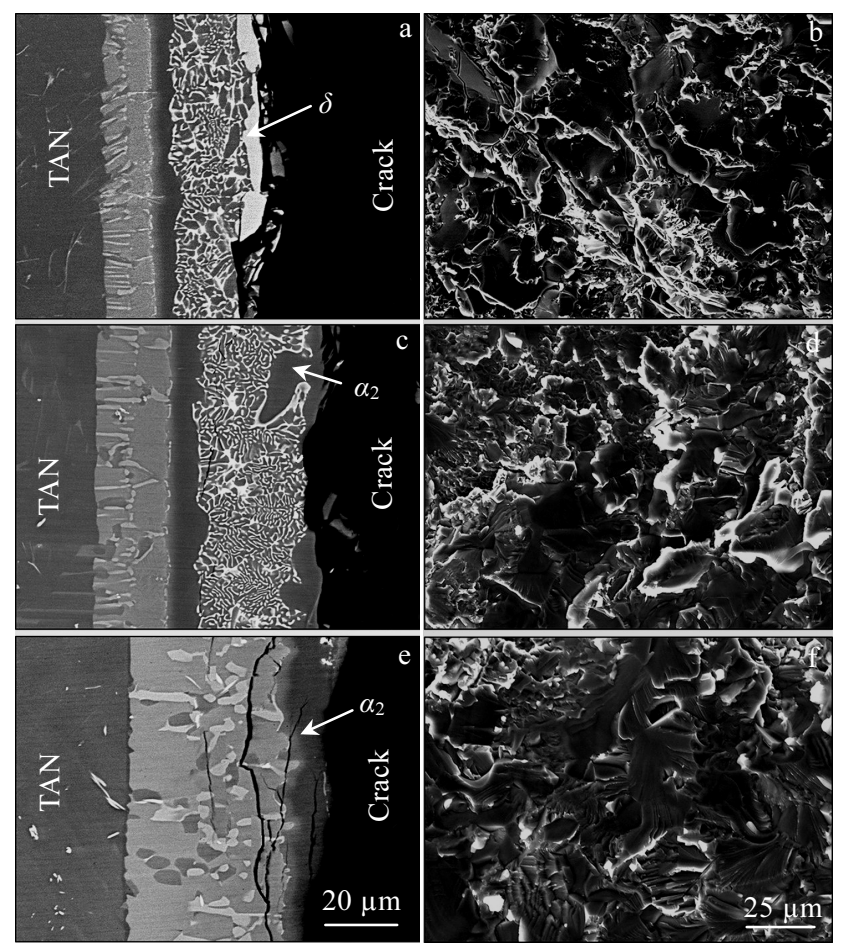

Fig.7 Cross-section BSE images and fracture SE images of TAN joints brazed at $1100{ }^{\circ} \mathrm{C}$ for different time after RT shear test: (a, b) $0 \mathrm{~min},(\mathrm{c}, \mathrm{d}) 15 \mathrm{~min}$, and (e, f) $90 \mathrm{~min}$

properties to some extent although the continuous $\alpha_{2}-\mathrm{Ti}_{3} \mathrm{Al}$ layers are inevitably formed in the joints. Moreover, the coarseness of $\tau_{3}-\mathrm{Al}_{3} \mathrm{Ti}_{2} \mathrm{Ni}$ phases and $\mathrm{B} 2$ phases in diffusion zones is also detrimental to the joints properties when holding time is prolonged over $90 \mathrm{~min}$, which causes some microcracks in diffusion zones, as shown in Fig. 7e.

\section{Conclusions}

1) Reliable brazing of the TAN alloy is achieved using Ti-28Ni eutectic brazing alloy at $1100{ }^{\circ} \mathrm{C}$ for $0 \sim 180 \mathrm{~min}$. The typical interfacial microstructure of TAN brazed joint is $\mathrm{TAN} / \tau_{3}-\mathrm{Al}_{3} \mathrm{Ti}_{2} \mathrm{Ni}+\mathrm{B} 2 / \alpha_{2}-\mathrm{Ti}_{3} \mathrm{Al}$ layer $/ \alpha_{2}-\mathrm{Ti}_{3} \mathrm{Al}+$ $\delta-\mathrm{Ti}_{2} \mathrm{Ni} / \alpha_{2}-\mathrm{Ti}_{3} \mathrm{Al}$ layer $/ \tau_{3}-\mathrm{Al}_{3} \mathrm{Ti}_{2} \mathrm{Ni}+\mathrm{B} 2 / \mathrm{TAN}$.

2) The diffusion of element $\mathrm{Ni}$ from molten brazing alloy to TAN substrate plays an important role in the interfacial microstructure evolution, which results in an increase of diffusion zone and a decrease of brazed seam with the prolongation of holding time. Moreover, the continuous $\alpha_{2}-\mathrm{Ti}_{3} \mathrm{Al}$ layer is insensitive to holding time.

3) The highest average RT shear strength and HT shear strength reach 248.6 $\mathrm{MPa}$ and 166.4 $\mathrm{MPa}$, respectively when TAN alloy is brazed at $1100{ }^{\circ} \mathrm{C}$ for $15 \mathrm{~min}$. Brittle fracture prefers to initiate and propagate in the continuous intermetallic layers $\left(\mathrm{Ti}_{2} \mathrm{Ni}\right.$ layer or $\mathrm{Ti}_{3} \mathrm{Al}$ layer $)$ during shear test. The two-phase mixed region in brazed joints could improve the joint properties to some extent.

\section{References}

1 Tetsui T, Ono S. Intermetallics[J], 1999, 7: 689

2 Noda T. Intermetallics[J], 1998, 6: 709

3 Zhang W J, Lorenz U, Appel F. Acta Materialia[J], 2000, 48: 2803

4 Zhu D D, Dong D, Ni C $\mathrm{Y}$ et al. Materials Characterization $[\mathrm{J}], 2015$, 99: 243

5 Kim S W, Hong J K, Na Y S et al. Materials \& Design[J], 2014, 54: 814

6 Ding X F, Lin J P, Zhang L Q et al. Materials \& Design[J], 2011, 32: 395

7 Li J B, Liu Y, Liu B et al. Materials Characterization[J], 2014, 95: 148

8 Zhang S Z, Kong F T, Chen Y Y et al. Intermetallics[J], 2012, 31: 208

9 Wang Y H, Liu J P, He Y H et al. Materials Science and Engineering $A[\mathrm{~J}], 2008,489: 55$

10 Chaturvedi M C, Xu Q, Richards N L. Journal of Materials Processing Technology [J], 2001, 118: 74

11 Cao J, Liu J K, Song X G et al. Materials \& Design[J], 2014, 56: 115

12 Qu H P, Li P, Zhang S Q et al. Materials \& Design[J], 2010, 31: 574

13 Wu G Q, Huang Z, Chen C Q et al. Materials Science and Engineering $A[\mathrm{~J}], 2004,380: 402$

14 Shiue R K, Wu S K, Chen S Y. Intermetallics[J], 2004, 12: 929

15 Shiue R K, Wu S K, Chen S Y. Acta Materialia[J], 2003, 51: 1991

16 Li X Q, Li L, Hu K et al. Intermetallics[J], 2015, 57: 7

17 Shiue R K, Wu S K, Chen Y T et al. Intermetallics [J], 2008, 16: 1083

18 Song X G, Cao J, Chen H Y et al. Materials Science and Engineering $A[\mathrm{~J}], 2012,551: 133$

19 Song X G, Cao J, Liu Y Z et al. Intermetallics[J], 2012, 22: 136

20 Lin T S, Li H X, He P et al. Intermetallics[J], 2013, 37: 59

21 He P, Liu D, Shang E et al. Materials Characterization[J], 
2009, 60: 30

22 Engineering $A[\mathrm{~J}], 2015,636: 522$

23 Huneau B, Rogl P, Zeng K et al. Intermetallics[J], 1999, 7:
1337

24 Schuster J C, Pan Z, Liu S H et al. Intermetallics[J], 2007, 15: 1257

25 Mishin Y, Herzig C. Acta Materialia[J], 2000, 48(3): 589

\section{高铌 TiAl 合金钎焊接头组织和性能研究}

宋晓国, 司晓庆, 曹 健, 王志权, 赵洪运, 冯吉才

(哈尔滨工业大学 先进焊接与连接国家重点实验室, 黑龙江 哈尔滨 150001)

摘 要: 采用 $\mathrm{Ti}-28 \mathrm{Ni}$ (质量分数, \%) 共晶钎料在 $1100{ }^{\circ} \mathrm{C}$ 实现了高铌 $\mathrm{TiAl}$ 合金 $(\mathrm{Ti}-45 \mathrm{Al}-8.5 \mathrm{Nb}-(\mathrm{W}, \mathrm{B}, \mathrm{Y})(\mathrm{at} \%), \mathrm{TAN})$ 的真空钎焊连接。 钎焊接头的典型界面结构为 $\mathrm{TAN} / \tau_{3}-\mathrm{Al}_{3} \mathrm{Ti}_{2} \mathrm{Ni}+\mathrm{B} 2 / \alpha_{2}-\mathrm{Ti}{ }_{3} \mathrm{Al}$ layer $/ \alpha_{2}-\mathrm{Ti}_{3} \mathrm{Al}+\delta-\mathrm{Ti}_{2} \mathrm{Ni}_{2} / \alpha_{2}-\mathrm{Ti}_{3} \mathrm{Al}$ layer $/ \tau_{3}-\mathrm{Al}_{3} \mathrm{Ti}_{2} \mathrm{Ni}+\mathrm{B} 2 / \mathrm{TAN}$ 。深入研究了保温 时间对钎焊接头界面组织和连接性能的影响。结果表明: Ni 元素从熔融钎料向 TAN 母材的扩散决定了界面组织的演化, 随着保温时 间的延长促进了扩散层的增厚, 同时导致钎缝宽度逐渐减小。接头剪切强度测试结果显示, 当保温时间为 $15 \mathrm{~min}$ 时, 获得的最大接头 室温剪切强度和高温 $\left(600{ }^{\circ} \mathrm{C}\right)$ 剪切强度分别是 248.6 和 $166.4 \mathrm{MPa}$ 。接头断口分析表明在剪切试验中裂纹主要沿着连续的金属间化合物 层产生和扩展。

关键词: TiAl金属间化合物; 真空钎焊; 界面组织; 力学性能; 断口

作者简介: 宋晓国, 男, 1983 年生, 博士, 副教授, 哈尔滨工业大学先进焊接与连接国家重点实验室, 黑龙江 哈尔滨 150001, E-mail: songxg@hitwh.edu.cn 